\title{
Genetic Determinants of Microvascular Complications in Type 1 Diabetes
}

\author{
Constantina Heltianu ${ }^{1}$, Cristian Guja ${ }^{2}$ and Simona-Adriana Manea ${ }^{1}$ \\ ${ }^{1}$ Institute of Cellular Biology and Pathology "N. Simionescu", Bucharest, \\ 2Institute of Diabetes, Nutrition and Metabolic Diseases "Prof. NC Paulescu", Bucharest,
}

Romania

\section{Introduction}

Diabetes mellitus is one of the most prevalent chronic diseases of modern societies and a major health problem in nearly all countries. Its prevalence has risen sharply worldwide during the past few decades (Amos et al., 1997; Shaw et al., 2010). Moreover, predictions show that diabetes prevalence will continue to rise, reaching epidemic proportions by 2030: $7.7 \%$ of world population, representing 439 million adults worldwide (Shaw et al., 2010). This increase is largely due to the epidemic of obesity and consequent type 2 diabetes (T2DM). However, the incidence of type 1 diabetes (T1DM) is also rising all over the world (DiaMond Project Group, 2006; Maahs et al., 2010). Recent data for Europe (Patterson et al., 2009) predict the doubling of new cases of T1DM between 2005 and 2020 in children younger than 5 years and an increase of $70 \%$ in children younger than 15 years, old.

Despite major progresses in T1DM treatment during the past decades, mortality in T1DM patients continues to be much higher than in general population, with wide variations in mortality rates between countries. In Europe, these variations are not explained by the country T1DM incidence rate or its gross domestic product, but are greatly influenced by the presence of its chronic complications, especially diabetic renal disease (Groop et al., 2009; Patterson et al., 2007). In fact, much of the health burden related to T1DM is created by its chronic vascular complications, involving both large (macrovascular) and small (microvascular) blood vessels.

Many genetic, metabolic and hemodynamic factors are involved in the genesis of diabetic vascular complications. However, major epidemiological and interventional studies showed that chronic hyperglycemia is the main contributor to diabetic tissue damage (DCCT Research Group, 1993). If the degree of metabolic control remains the main risk factor for the development of diabetic chronic complications, an important contribution can be attributed to genetic risk factors, some of them common for all microvascular complications (diabetic retinopathy, neuropathy, and renal disease) and some specific for each of them (Cimponeriu et al., 2010). Additional factors are represented by some accelerators such as hypertension and dyslipidemia.

In the following pages, we present briefly the pathogenesis type 1 diabetes and its chronic microvascular complications. The main information of the genetic background in T1DM with particular focus on gene variants having strong impact on endothelial dysfunction as the key factor in the development of microvascular disorders are also summarized. 


\section{Type 1 diabetes mellitus}

T1DM is a common, chronic, autoimmune disease characterized by the selective destruction of the insulin secreting pancreatic beta cells, destruction mediated mainly by the T lymphocytes (Eisenbarth, 1986). The destruction of the insulin secreting pancreatic beta cells is progressive, leading to an absolute insulin deficiency and the need for exogenous insulin treatment for survival. The pathogenic factors that trigger anti beta cell autoimmunity in genetically predisposed subjects are not yet fully elucidated, but there is clear evidence that it appears consequently to an alteration of the immune regulation. The destruction of the beta cells in T1DM is massive and specific and it is associated with some local (Gepts, 1965) or systemic (Bottazzo et al., 1978) evidence of anti-islet autoimmunity.

It is currently considered that, on the "background" of genetic predisposition, some putative environmental trigger factors will initiate the autoimmune process that will finally lead to T1DM. Identifying these triggers proved to be difficult, mainly due to a long period of time elapses between the intervention of the putative environmental trigger and the clinical onset of overt diabetes. The most important factors seem to be non-genetic external (environmental) ones. However, from environmental factors repeatedly associated with T1DM, the most important were viral infections, dietary and nutritional factors, nitrates and nitrosamines, etc. (Akerblom et al., 2002).

Genetic factors in the pathogenesis of T1DM in humans. T1DM is a common, complex, polygenic disease, with many predisposing or protective gene variants, interacting with each other in generating the global genetic disease risk (Todd, 1991). The study of candidate genes identified several susceptible genes for T1DM (Concannon et al., 2009): IDDM1 encoded in the HLA region of the major histocompatibility complex (MHC) genes on chromosome 6p21 and genes mapped to the DRB1, DQB1 and DQA1 loci, IDDM2 encoded by the insulin gene on chromosome 11p15.5 and mapped to the VNTR $5^{\prime}$ region, IDDM12 encoded by the cytotoxic $\mathrm{T}$ lymphocite associated antigen 4 (CTLA4) gene on chromosome 2q33, the lymphoid tyrosine phosphatase 22 (PTPN22) gene on chromosome 1p13 and the IL2RA/CD25 gene on chromosome 10p15. The genome wide linkage (GWL) analysis strategies (Morahan et al., 2011) or genome wide association (GWA) techniques (Todd et al., 2007) led to the identification of other T1DM associated loci, for most of which the causal genes are still not elucidated.

\section{Chronic complications in T1DM}

T1DM is characterized by the slow progression towards the generation of some specific lesions of the blood vessels walls, affecting both small arterioles and capillaries (microangiopathy) and large arteries (macroangiopathy). The "classical" diabetes microvascular complications are represented by diabetic retinopathy (DR) the main cause of blindness, diabetic nephropathy (DN) also known as renal disease, the main cause of renal substitution therapy (dialysis or renal transplantation) in developed countries, and diabetic neuropathy (DPN) as reported (IDF, 2009). As we already mentioned, chronic hyperglycemia represents the key determinant in the development of T1DM chronic microvascular complications. Meanwhile, considerable biochemical and clinical evidence (Hadi \& Suwaidi, 2007) indicated that endothelial dysfunction is a critical part of the pathogenesis of vascular complications both in T1DM and T2DM. 
Several mechanisms explain the contribution of chronic hyperglycemia to the development of endothelial dysfunction and chronic diabetes complications. An unifying mechanism was proposed by Michael Brownlee, suggesting that overproduction of superoxide anion $\left(\mathrm{O}_{2}^{-}\right)$by the mitochondrial electron transport chain might be the key element (Brownlee, 2005). According to this theory, hyperglycemia determines increased mitochondrial production of reactive oxygen species (ROS). Increased oxidative stress induces nuclear DNA strand breaks that, in turn, activate the enzyme poly ADN-ribose polymerase (PARP) leading to a cascade process that finally activates the four major pathways of diabetic complications: (1) Increased aldose reductase activity and activation of the polyol pathway lead to increased sorbitol accumulation with osmotic effects, NADPH depletion and decreased bioavailability of nitric oxide (NO). (2) Activation of protein kinase $C$ with subsequent activation of NF-kB pathway and superoxide-producing enzymes. (3) Advanced glycation end-products (AGEs) generation with alteration in the structure and function of both intracellular and plasma proteins. (4) Activation of the hexosamine pathway leads to a decrease in endothelial NO synthase (NOS3) activity as well as an increase in the transcription of the transforming growth factor (TGF- $\beta$ ) and the plasminogen activator inhibitor-1 (PAI-1) as reported (Brownlee, 2005).

In Europe, the prevalence of DN was estimated at 31\%, DR was diagnosed in $35.9 \%$ of patients while proliferative DR in $10.3 \%$. Apart hyperglycemia, the most important risk factor was the duration of the disease. Thus, the prevalence of proliferative DR is null before 10 years diabetes duration but $40 \%$ after 30 years duration while the prevalence of DN is null before 5 years diabetes duration but reaches $40 \%$ after 15 years of diabetes (EURODIAB IDDM Complications Study Group, 1994). Similar data were provided by the diabetes control and complications trial (DCCT) study in USA. Thus, after 30 years of diabetes, the cumulative incidence of proliferative DR and DN was $50 \%$ and $25 \%$, respectively, in the DCCT conventional treatment group (DCCT/EDIC Research Group et al., 2009).

\subsection{Diabetic nephropathy}

$\mathrm{DN}$ in T1DM can be defined by the presence of increased urinary albumin excretion rate (UAER) on at least two distinct occasions separated by 3-6 months (Mogensen, 2000). DN is usually accompanied by hypertension, progressive rise in proteinuria, and decline in renal function. According to several guidelines, normal UAER is defined as an excretion rate below $30 \mathrm{mg} / 24 \mathrm{~h}$; microalbuminuria represents an UAER between 30-300 mg/24 h while more than $300 \mathrm{mg} / 24 \mathrm{~h}$ defines overt proteinuria. In T1DM, five DN stages have been proposed (Mogensen, 2000). Stage 1 is characterized by renal hypertrophy and hyperfiltration, being frequently reversible with good metabolic control. Stage 2 is typically asymptomatic and lasts for an average of 10 years. Typical histological abnormalities include diffuse thickening of the glomerular and tubular basement membranes as well as glomerular hypertrophy. About $30 \%$ of subjects will progress towards microalbuminuria. Stage 3 (incipient DN) develops 10 years after the onset of diabetes. Microalbuminuria, the earliest clinically detectable sign, is well correlated with histological findings of nodular glomerulosclerosis. About $80 \%$ of subjects will progress to overt proteinuria. This proportion may decrease with tight glycemic control, hypoproteic diet and early treatment with angiotensin I-converting enzyme (ACE) inhibitors or angiotensin II receptor (Ang II R) blockers. Stage 4 (clinical or late DN) occurs on average 15-20 years after diabetes onset and is characterized by macroalbuminuria. The glomerular filtration rate (GFR) declines progressively, UAER increases usually to more than $500 \mathrm{mg} /$ day and blood pressure starts 
to rise. Histologically, mesangial expansion develops, renal fibrosis becomes more evident and leads to diffuse and nodular glomerulosclerosis. Stage 5 (end-stage renal disease) occurs on average 7 years after the development of persistent proteinuria. GFR decreases below 40 $\mathrm{ml} / \mathrm{min}$ and an advanced destruction of all renal structures is observed.

DN pathogenesis is very complex and comprises both metabolic and haemodynamic factors in the renal microcirculation (Stehouwer, 2000). The glucose dependent pathways were presented briefly above. Haemodynamic factors mediate renal injury via effects on systemic hypertension, intraglomerular haemodynamics or via direct effects on renal production of cytokines, such as TGF $\beta$ and vascular endothelial growth factor (VEGF), or hormones such as angiotensin II or endothelin (ET) as reported (Schrijvers et al., 2004). In addition to the diabetes duration reflected by the level of glycated hemoglobin ( $\mathrm{HbA1c})$, the specific risk factors for DN are the blood pressure, older age, male sex, smoking status, and ethnic background.

Despite clear evidence for the role of genetic factors in DN, success in identifying the responsible genetic variants has been limited due to both objective and subjective difficulties, the main being represented by the small size of the DNA collections available to individual research groups (Pezzolesi et al., 2009). Strategies for the genetic investigation of DN included the analysis of candidate gene polymorphisms in case-control settings (hypothesis driven approach) as well as the GWL or GWA strategies with DN (hypothesis free approach). Numerous candidate genes were tested explaining the complexity of the diabetic renal disease pathogenesis (Cimponeriu et al., 2010; Mooyaart et al., 2011) but just few of them were reconfirmed in multiple, independent, studies. We give a list of the stronger associations in Table 1.

\begin{tabular}{|c|c|c|c|c|c|c|}
\hline Gene & $\begin{array}{l}\text { Chromo } \\
\text { some }\end{array}$ & SNP & Allele & $\begin{array}{c}\text { No. } \\
\text { studies }\end{array}$ & $\begin{array}{l}\text { Case/ } \\
\text { Control }\end{array}$ & OR \\
\hline$A C E$ & $17 q 23$ & rs179975 & $\bar{D}$ & 14 & $2215 / 2685$ & 1.13 \\
\hline \multirow{3}{*}{$A K R 1 B 1$} & \multirow{3}{*}{$7 q 35$} & $(A C) n$ repeat & Z-2 & 10 & $1380 / 1308$ & 1.12 \\
\hline & & $(A C) n$ repeat & $Z+2$ & 10 & $1380 / 1308$ & 0.79 \\
\hline & & rs759853 & $T$ & 4 & $636 / 537$ & 1.58 \\
\hline$A P O C 1$ & $19 q 13.2$ & rs4420638 & $G$ & 2 & $857 / 935$ & 1.54 \\
\hline$A P O E$ & $19 \mathrm{q} 13.2$ & $E 2 / E 3 / E 4$ & $E 2$ & 6 & $889 / 803$ & 1.48 \\
\hline$E P O$ & $7 q 21$ & rs1617640 & $T$ & 2 & $1244 / 715$ & 0.67 \\
\hline GREM1 & 15q13-q15 & $r s 1129456$ & $T$ & 2 & $859 / 940$ & 1.53 \\
\hline HSPG2 & $1 \mathrm{p} 36.1$ & $r s 3767140$ & $G$ & 2 & $417 / 240$ & 0.64 \\
\hline \multirow[t]{2}{*}{ NOS3 } & \multirow[t]{2}{*}{$7 q 36$} & rs3138808 & $\begin{array}{c}a \text {-del } \\
393 \mathrm{bp}\end{array}$ & 3 & $679 / 657$ & 1.45 \\
\hline & & rs2070744 & C & 2 & $273 / 450$ & 1.39 \\
\hline UNC13B & 9 & rs13293564 & $T$ & 4 & $1572 / 1910$ & 1.23 \\
\hline VEGFA & 6p12 & rs833061 & $C$ & 2 & $242 / 301$ & 0.48 \\
\hline
\end{tabular}

Table 1. Gene variants associated with DN in T1DM subjects. Identified by candidate gene study and confirmed after meta-analysis of at least 2 studies (adapted from a recent report, Mooyaart et al., 2011). I-converting $A C E$, angiotensin I-converting enzyme; $A K R 1 B 1$, aldose reductase; $A P O C 1$, apoprotein $C 1$; $A P O E$, apoprotein E; EPO, erythropoietin; GREM1, gremlin 1 homolog; HSPG2, heparan sulfate proteoglycan; NOS3, endothelial nitric oxide synthase; UNC13B, presynaptic protein; VEGFA, vascular endotehlial growth factor A. 


\subsection{Diabetic retinopathy}

$\mathrm{DR}$ is one of the most severe diabetes complications, potentially leading to severe sight decrease or even blindness. The first clinical signs of DR (incipient, non-proliferative DN) are retinal microaneurysms, dot intraretinal hemorrhages and hard exudates (Frank, 2004). The most severe stage, proliferative DR, is characterized by retinal haemorrhages from fragile neo-vessels and, in advanced eye disease by vitreous hemorrhages and tractional detachments of the retina, both resulting in visual loss. Histologically, DR is characterized by a selective loss of pericytes from the retinal capillaries followed by the loss of capillary endothelial cells (Frank, 2004). DR pathogenesis is complex, involving both metabolic and haemodynamic factors. The most important DR specific pathways seem to be the local production of several polypeptide growth factors, including VEGF, pigment-epitheliumderived factor (PEDF), growth hormone and insulin-like growth factor-1, as well as cytokines and inflammatory mediators such as TNFa, TNF $\beta$, TGF $\beta$ and NO (Frank, 2004). Genetic factors appear also to have an important role in generating the DR risk in T1DM subjects with similar degrees of metabolic control and disease duration (Keenan et al., 2007). The most often studied DR candidate genes include blood pressure regulators (RAS), metabolism factors (AKR1B1, AGER, GLUT1), growth factors (VEGF, PEDF), NOS2A, NOS3, TNFa, TGF $\beta$, ET-1 and its receptors, etc. (Cimponeriu et al., 2010; Ng, 2010). As for all diabetes chronic complications, the studies of candidate genes were more often underpowered to detect true associations, and most often the results were not reconfirmed by additional, independent studies. However, published meta-analyses suggest a real role in DR for at least four genes (Abhary et al., 2009a; Cimponeriu et al., 2010; Ng, 2010).

Similar with DN, ACE gene was the most studied for DR in T1DM and data regarding its involvement will be presented further (see subchapter 6.1). VEGFA gene on chromosome 6p12-p21 was also intensively studied and a recent large study (including both T1DM and T2DM cases) suggested a possible effect of two gene variants ( $r$ s699946 and $r$ s833068) on DR risk in T1DM subjects (Abhary et al., 2009b). Among the candidate genes from the oxidative stress/increased ROS pathway, NOS3 gene was intensively studied in DR and data will be presented in subchapter 4.3. Finally, maybe the strongest evidence for a role in the genetic risk for DR is provided by the analysis of $A K R 1 B 1$ gene on chromosome $7 \mathrm{q} 35$, encoding the rate-limiting enzyme of the polyol pathway. The most intensively studied polymorphism was the $(A C) n$ microsatellite located at $2.1 \mathrm{~kb}$ upstream of the transcription start site $(Z-2, Z$ and $Z+2$ alleles). A recent meta-analysis (Abhary et al., 2009a) showed that the $Z-2$ allele of the $(C A) n$ microsatellite is significantly associated with DR risk in both T1DM and T2DM subjects. In addition, the $T$ allele of rs759853 in the AKR1B1 promoter seems to be protective. To our best knowledge, no attempts for both GWL and GWA for identification of DR genes in T1DM were reported so far.

\subsection{Diabetic polyneuropathy}

DPN is a chronic microvascular complication affecting both somatic and autonomic peripheral nerves. It may be defined as the presence of symptoms and/or signs of peripheral nerve dysfunction in people with diabetes, after the exclusion of other causes of neuropathy. Many neuropathic patients have signs of neurological dysfunction upon clinical examination, but have no symptoms at all (negative symptoms neuropathy). On the contrary, some patients have positive symptoms (burning, itching, freezing, sometimes intense pain and often with nocturnal exacerbations), usually with distal onset and proximal 
progression. This form is designated as painful DPN. Correct estimates regarding the prevalence of DPN are hard to obtain since the diagnosis of the "negative symptom patients" can be made only by active screening, usually with complex investigations such as nerve conduction velocity.

It is generally accepted that DPN results from the micro-angiopathy damage of the vasa nervorum (responsible for the microcirculation of neural tissue) associated with the direct damage of neuronal components induced by various metabolic factors, the most important being chronic hyperglycemia (Kempler, 2002). The vascular and metabolic mechanisms act simultaneously and have an additive effect. The most important links between the two are represented by the local NO depletion and failure of antioxidant protection, both resulting in increased oxidative stress. Apart the unquestionable role of chronic hyperglycemia (diabetes duration and level of metabolic control), other risk factors for DPN are increasing age, cigarette smoking, alcohol or other drug abuse, hypertension and hypercholesterolemia.

Data regarding the genetic background of DPN are rather scarce. To our best knowledge, no GWL or GWA were performed for the identification of DPN genes in T1DM. Several data regarding the effect of some candidate genes were published, but these included usually only small number of patients/controls and few were replicated in other, independent datasets. Maybe the most significant effect on DPN genetic risk in T1DM is conferred by variants of the AKR1B1 gene. Other significant but not reconfirmed associations with the risk for DPN were reported for variants of PARP-1, NOS2A, NOS3, uncoupling protein $U C P 2$ and UCP3, genes encoding the antioxidant proteins, catalase and the superoxide dismutase, and the gene encoding the neuronal $\mathrm{Na}^{+} / \mathrm{K}^{+}$-ATPase (Cimponeriu et al., 2010).

In conclusion, during the past two decades we have witnessed an explosion of studies regarding the genetic background of diabetes microvascular complications, both in T1DM and T2DM. These efforts, mainly focusing on candidate genes and often using study groups underpowered to detect genuine associations, have contributed to the identification of a few credible predisposing gene variants (Doria, 2010). In order to make significant progresses in elucidating the genetics of microvascular complications, there is an urgent need for assembling large population collections of different backgrounds for both GWA scanning and candidate gene association studies.

\section{Nitric oxide synthase genes}

$\mathrm{NO}$ is one of the vasodilatory substances released by the endothelium and has the crucial role in vascular physiopathology including regulation of vascular tone and blood pressure, hemostasis of fibrinolysis, and proliferation of vascular smooth muscle cells (SMC). In T1DM, NO has an increased stimulatory effect on the released insulin from $\beta$ cells, mostly to the early phase of the effect of glucose upon insulin secretion. Abnormality in its production and action can cause endothelial dysfunction leading to increased susceptibility to hypertension, hypercholesterolemia, diabetes mellitus, thrombosis and cerebrovascular disease. Serum nitrite and nitrate (NOx) concentrations assessed as an index of $\mathrm{NO}$ production was used as a marker for endothelial function.

In DN, the NO production was significantly higher. A strong link between circulating NO, glomerular hyperfiltration, and microalbuminuria in young T1DM patients with early nephropathy was reported (Chiarelli et al., 2000). It has been postulated that in diabetic kidney there is increased NO synthase (NOS) activity, and the excessive NO production can 
induce the renal hyperfiltration and hyperperfusion and by its perturbing effect contributes to the DN appearance (Bazzaz et al., 2010). In early diabetes, the retinal circulation devoided of any extrinsic innervation and depending entirely on endothelium-mediated autoregulation, is dramatically affected by the ECs dysfunction due to the lack of the local NO, a state seen in DR (Qidwai \& Jamal, 2010).

In active progressive DR, aqueous NO levels are significantly high, while plasma NO levels remained at the level of diabetics without DR (Yilmaz et al., 2000). Raised plasma NO levels in T1DM patients were reported (Heltianu et al., 2008) indicating that pathogenesis of diabetic-associated vascular complications is connected with a generalized increased synthesis of NO throughout the body. This phenomenon occurs early in the natural course of diabetes and independently of the presence of microvascular complications. So, we suggest that the high NO levels found in diabetic patients (including those without any clinically manifested microangiopaties) might represent an overproduction of $\mathrm{NO}$ that is associated with diffuse endothelial dysfunction (Heltianu et al., 2008).

There is a family of NOS enzymes which produces NO. The two constitutive isoforms NOS1 (neuronal) and NOS3 (endothelial) as well as the inducible isoform NOS2 have similar enzymatic mechanisms but are encoded on separate chromosomes by different genes. The NOS1 gene is located on chromosome 12q24.2-24.31, has 29 exons, spaning a region greater than $240 \mathrm{~kb}$ and encodes a protein of $\sim 161 \mathrm{kDa}$. The NOS2A gene is on chromosome 17q11.2-12 having 27 exons, spaning $37 \mathrm{~kb}$ and encodes a protein of $\sim 131 \mathrm{kDA}$ (Li et al., 2007). NOS3 gene is on chromosome 7q35-36, includes 26 exons, having a genomic size of 21 $\mathrm{kb}$, and encodes a protein of $\sim 133 \mathrm{kDa}$ (Chen et al., 2007; http://www.genecards.org, version 3).

\subsection{NOS1 gene}

The NOS1-derived NO is implicated in local regulation of vascular tone and blood flow using different mechanisms. This process appears to be independent of central NOS1 action on autonomic function (Melikian et al., 2009). In the early stages of diabetes, the NOS1 expression in the nitrergic axons decreases and its level in the cell bodies is unaffected probably due to a defect in axonal transport. Insulin treatment is able to reverse NOS1 decrease. With the progression of diabetes, NOS1 accumulates in the cell bodies due to an affected transport down to the axons, and the degenerative changes become irreversible without any response to insulin treatment (Cellek, 2004). The NOS1 gene has 12 different potential first exons $(1 A-1 L)$ and as consequence the NOS1 protein is expressed as a very complex enzyme (Wang et al., 1999). The NOS1B is expressed in renal microvasculature (Freedman et al., 2000). To our knowledge, there are only two reports in which NOS1 polymorphisms were analyzed for the relationship with diabetic microvascular disorders. Microsatellite markers in NOS1B were assessed in T2DM and an association with ESDR for alleles 7 and 9 was reported (Freedman et al., 2000). The CA repeat in the 3'-UTR region (exon 29) of NOS1 was found not to be a risk for DPN (Zotova et al., 2005).

\subsection{NOS2A gene}

NOS2A gene has the transcription start site in exon 2 and the stop codon in exon 27. This gene encodes NOS2 protein which has two different functional catalytic enzyme domains, the oxygenase domain encoded by 1 to 13 exons, and reductase domain by 14 to 27 exons. The NOS2 differs from the constitutive forms (NOS1 and NOS3) being $\mathrm{Ca}^{2+}$ independent. 
Due to strong binding of calmodulin to NOS2, this is insensitive to changes in calcium ion concentrations (Jonannesen et al., 2001; Qidwai \& Jamal, 2010). Under normal conditions, NOS2 is not expressed. Exposure to high ambient glucose or cytokines, the upregulation of NOS2 occurs in a variety of cell type and tissues. As a consequence, a sudden burst of NO synthesis occurs leading to severe vasodilation and circulatory collapse. In diabetic milieu as long as NOS3 expression is low, the induction of NOS2 expression may occur in an attempt to achieve homeostasis, being crucial in preventing or delaying pathological alterations in the microcirculation (Warpeha \& Chakravarthy 2003). In studies of diabetic complications, as DR and DN, influenced by vascular functional disturbances, the increased NO formation via NOS2 expression has been reported (Johannesen et al., 2000a).

In human NOS2A gene has been identified a large number of polymorphisms. In the promoter region there are single nucleotide polymorphisms $(-954 G / C,-1173 C / T,-1659 A / T)$ and two microsatellite repeats, the biallelic (TAAA)n, and the (CCTTT)n with nine alleles, which might affect the NOS2 transcription. Explanations for this modulation was proposed for $-1173 C / T$ polymorphism, when the $C$ to $T$ change predicts the formation of a new sequence recognition site for the GATA-1 or GATA-2 transcription factors, which further bind to specific DNA sequences and potentially increase the degree of mRNA transcription (Qidwai \& Jamal, 2010). The gene variants in the coding region might alter the activity of NOS2 with subsequence variability in the NO levels which might be responsible for the susceptibility or/and severity of the disease. Other polymorphisms in exons and introns were reported, rs16966563 (exon 4, Pro68Pro), rs1137933 (exon 10, Asp385Asp), rs2297518 (exon 16, Leu608Ser), rs3794763 (intron 5, G>A), rs17718148 (intron 11, C>T), rs2314809 (intron 17, $T>C$ ), and $r s 2297512$ (intron 20, $A>G$ ).

In T1DM, the NOS2A polymorphisms in the promoter region [-954G/C, (TAAA)n and (CCTTT)n] and exons (Asp346Asp and Leu608Ser) were analyzed and the results showed that none of them has a role in the development of the disease (Johannesen et al., 2000a). Using the transmission disequilibrium test, it was found in Caucasian population that there is an increased risk for T1DM among HLA DR3/4-positive individuals with a $T$ in position 150 in exon 16 (Leu608Ser) of NOS2A. This finding suggests an interaction between the NOS2A locus and the HLA region and a role for NOS2A in the pathogenesis of human T1DM (Johannesen et al., 2001).

Assessement of polymorphisms in T1DM for the prevalence of DR showed that the 14-repeat allele of (CCTTT)n repeat polymorphism in NOS2A was significantly associated with the absence of the disease. A person with diabetes carrying this allele has 0.21 -fold chance of developing retinopathy as compared to those not carrying the allele, suggesting that the carriage of the 14-repeat allele is not a feature of diabetes itself, but is specific to DR development (Warpeha et al., 1999; Warpeha \& Chakravarthy, 2003). In addition, the same NOS2A variant, the 14-repeat allele, was found to represent a low risk for DN (Johannesen et al., 2000b), and other report indicated that carriers of this allele have the low risk of DPN in T1DM (Nosikov, 2004; Zotova et al., 2005).

\subsection{NOS3 gene}

NOS3 is the most relevant and frequent isoform studied to assess the role of genetic issues in the development of angiopathic disease in T1DM. This enzyme is a constitutively expressed in vascular endothelial cells, and the protein expression depends on $\mathrm{Ca}^{2+}$ and calmodulin. It was suggested a possible dual functionality of NO. Excessive production of 
$\mathrm{NO}$, in $\mathrm{DN}$, induces the renal hyperfiltration and hyperperfusion and contributes to the vascular disorder. More often, reduced NO production or availability was reported in other vascular pathologies. The effect of $\mathrm{NO}$ on the endothelial modulation is influenced by the duration of diabetes; so, at early stages of diabetes the endothelial function is enhanced, and with the progression of diabetic duration the endothelial dysfunction is accelerated (Bazzaz et al., 2010; Chen et al., 2007; Mamoulakis et al., 2009).

Several polymorphisms have been reported in NOS3 promoter, exon and intron regions (Table 2). The most studied variant from the promoter region was the single nucleotide polymorphism at position -786 where there is a base substitution from $T$ to C (rs2070744). In previous studies it was shown that individuals with $-786 \mathrm{C}$ allele had a reduced activity of the NOS3 gene promoter (Taverna et al., 2005), explained by the fact that DNA binding protein (replication protein A1) has the ability to bind only to the $-786 \mathrm{C}$ allele resulting a $\sim 50 \%$ reduced NOS3 transcription, with the subsequent decrease in both protein expression and serum NOx levels (Erbs et al., 2003). The interrelationships among rs2070744 genotypes, NOS3 (mRNA, protein levels, and enzymatic activity), and plasma NOx levels have never been linear.

NOS3 polymorphism in intron $4(4 a / 4 b)$ is based on a variable 27-base pair tandem repeat four (allele $4 a$ ), five (allele $4 b$ ) or six (allele $4 c$ ) repeats. Previous studies have suggested that deletion of one of the five nucleotide repeats in intron 4 could affect the rates of NOS3 transcription and processing rate, thus resulting the modulation of NOS3 enzymatic activity and, apparently, affecting the plasma NOx concentrations (Zanchi et al., 2000), with the potentiality of this genotype to have an effect on microangiopathy later on in diabetic life (Mamoulakis et al., 2009).

\begin{tabular}{|c|ccc|}
\hline SNP ID & $\begin{array}{c}\text { Chromosome } \\
\text { position }\end{array}$ & Location type & Alleles \\
\hline & & intron 4 & $4 b / 4 b a$ \\
743507 & 150707488 & intron & $A / G$ \\
1799983 & 150696111 & exon & $G / T$ \\
1800783 & 150689397 & intron & $T / A$ \\
2070744 & 150690079 & the 5' promoter region & $T / C$ \\
2373929 & 150345745 & the 3' region & $G / A$ \\
2373961 & 150312143 & the 5' promoter region & $C / T$ \\
3138808 & & Del/Ins 393 bp & $D / I$ \\
3918188 & 150702781 & intron & $A / C / T$ \\
12703107 & 150314562 & the 5' region & $G / T$ \\
41322052 & 150690106 & intron & $C / T$ \\
\hline
\end{tabular}

Table 2. NOS3 gene polymorphisms. Source, http:/ / www.genecards.org; version 3

Carriers of the $4 a$ allele were found exhibiting $~ 20 \%$ lower NOx levels that appearing in $4 b / 4 b$ homozygous subjects. The regulation of NOS3 expression is more complicated considering the strong linked of $4 a / 4 b$ variant with $r s 2373961$ and $r s 2070744$ when the $b / b$ genotype might acts independently and in coordination with the other variants (Chen et al., 2007; Zintzaras et al., 2009). Among polymorphisms found in exons of NOS3, the G to T polymorphism at position 894 in exon 7 (rs1799983) was most studied. It was reported that 
this variant changes the NOS3 protein sequence, probable resulting an alteration of enzyme activity (Costacou et al., 2006), and control the NOS3 intracellular distribution interacting with proteins of degradating process (Brouet et al., 2001).

From many polymorphisms of the NOS3 gene some of them are associated with the development of diabetic microvascular complications while others indicated their protective role (Freedman et al., 2007; Heltianu et al., 2009). A recent study of $r s 2070744$ in Caucasian T1DM reported a positive association with diabetes per se as well as DR and two possible explanations were found; either NOS3 is a candidate gene for the microvascular disease, or there is a linkage disequilibrium between NOS3 and the neighbouring genes. It is known that in the same position (7q35) to NOS3 gene the AKR1B1 and T-cell receptor beta-chain (TCRBC) genes in the $7 q 34$ position are located (Bazzaz et al., 2010). In a hyperglycaemic milieu, the retinal NO bioavailability due to the presence of C-786 mutant allele of rs2070744 is decreased, and therefore the lack of NO stimulates aldose reductase, known to be implicated in the development of diabetes complications (Chandra et al., 2002). Other report showed that the onset pattern of severe DR in longstanding C-peptide-negative T1DM is affected by NOS3 rs2070744 and C774T polymorphisms (Taverna et al., 2005). In the case of C774T NOS3 polymorphism, the association with severe DR was related to the influence of the DN presence, which is a well-known strong risk factor for DR (Cimponeriu et al., 2010). Oppose, the rare allele $4 a$ of $4 b / 4 a$ variant of NOS3 was found to be related to absent or nonsevere DR in T1DM Caucasians patients, suggesting a protective role. Although the $4 b$ allele was more frequent among patients with severe DR, a modest effect on the microvascular disorder was evaluated from the broad confidence interval (Cheng et al., 2007). Recent reports and our studies showed that there were no relationships between $4 b / 4 a$ variant of NOS3 and DR or other microangiopathic complications. Similar results for rs1799983 in relation with DR were also reported (Heltianu et al., 2009; Mamulakis et al., 2009). In a metaanalysis of genetic association studies for DR in T1DM, from the three NOS3 polymorphisms (rs1799983, rs3138808 and rs41322052) included in the sub analysis for Caucasian subjects, none of them were found to be significantly associated with any form of DN (Abhary et al., 2009a)

The progression of renal disease was associated with the NOS3 rs2070744 variant (Freedman et al., 2007; Zanchi et al., 2000), a result confirm recently by meta-analysis (Mooyaart et al., 2011; Ned et al., 2010). Contradictory results were obtained for the relationship of NOS3 $4 b / 4 a$ polymorphism with DN. Some reports showed no association (Degen et al., 2001; Heltianu et al., 2009) and others indicated that the $4 a$ allele represents an excess risk for advanced DN (Nosikov, 2004; Zanchi et al., 2000; Zinzaras et al., 2009). It was hypothesized that the NOS3 $4 b / 4 a$ itself plays a role in tissue-specific regulation of NOS3 expression, a mechanism related to the importance of intron structure in the splicing of immature to mature RNA or to the presence of enhancer sequences within the intron 4 . On the other hand, both rs2070744 and 4b/4a polymorphisms were specifically associated with advanced $\mathrm{DN}$, and the $-786 \mathrm{C} / 4 a$ haplotype was reported to be transmitted from heterozygous parents to siblings with advanced DN, suggesting that the $4 a$ allele is coupled almost exclusively with the -786C allele of $r$ s2070744 (Zanchi et al., 2000). The NOS3 rs1799983 was analyzed in T1DM Caucazians from different countries and some reports showed no association with DN (Heltianu et al., 2009; Möllsten et al., 2009; Nosikov, 2004) and others found a marginal relationship (Ned et al., 2010) or strong association with increased risk of DN (Zintzaras et al., 2009). The $-786 \mathrm{C} / 894 T$ haplotype of NOS3 was found to be significantly associated with 
albuminuria, suggesting a strong implication of this gene in the susceptibility to kidney damage (Ned et al., 2010). The rs3138808 variant of NOS3 was also analyzed in a metaanalysis and was found to be associated with DN (Mooyaart et al., 2011).

There are only few reports which analyze the influence of NOS3 polymorphisms on DPN in T1DM. Data from Caucasian patients genotyped for $r s 1799983$ and $4 b / 4 a$ variants showed that both polymorphisms were not associated with DPN (Nosikov, 2004; Zotova et al., 2005). Our findings showed that only NOS3 $4 b / 4 a$ was not associated with DPN (Heltianu et al., 2009). In T1DM subjects with the lowest incidence of confirmed DPN, it was reported that the $894 \mathrm{G}$ carriers of $r s 1799983$ variant had fivefold increased risk for DPN, suggesting that despite low risk for the disease in these individuals, there is a genetic predisposition to develop diabetes-related complication (Costacou et al., 2006). In agreement with this report we found a prevalence of DPN among the 894GG as compared with 894TT homozygotes in diabetic patients with normal kidney function, suggesting that $894 G G$ genotype might be a risk factor for T1DM-related microvascular disease. This subgroup of DPN patients with 894GG had over 42\% DR as an additional vascular complication, and the presence or absence of DR did not modify the significance of the relationship between the $r s 1799983$ polymorphism and DPN. In addition, these subjects were recorded with high systolic blood pressure and raised levels of NOx, indicating a possible endothelial dysfunction, as well as with high levels of triglycerides, suggesting that additional high risk lipid profile contribute to the aggravation of the microvascular disorder. We presume that the rare-type $894 \mathrm{~T}$ allele might have a protective role against the development of DPN and a tendency to counterbalance increased NO production due to both chronic hyperglycemia and hypoxic effect at the microvascular level, by a not yet elucidated, compensatory-type mechanism (Heltianu et al., 2009).

Taken together, these results indicate that in T1DM, from various NOS3 polymorphisms the most studied were rs2070744, rs1799983 and 4b/4a variants. Even in Caucasians there are differences among populations for the effects of gene polymorphisms on the microvascular complications. Diverse factors contribute to the variations between studies, analysis of early or late microvascular complication, incidence of the studied disorder in subjects with other confirmed disease, small sample size, the lack of haplotype analysis. Further studies on larger numbers of samples and on different populations are required to confirm these results.

\section{Endothelin genes}

The family of endothelins (ET) is represented by three peptides (1 to 3) and two receptors (ETRA and ETRB), which are widely distributed, in different proportions, being mostly abundant in vascular endothelial cells (EC). Their ET-1 and ET-2 are strong vasoconstrictors, whereas ET-3 is a potentially weaker vasoconstrictor compared to the other two isoforms. The ET-1 which is the most potent vasoconstrictor peptide acts as a paracrine or autocrine factor and its effects are $\sim 10$ times higher that of angiotensin II. The ET- 1 has a variety of functions including its significant contribution to the maintenance of basal vascular tone, modulation of vascular permeability for proinflammatory mediators and proliferation of SMC. Having a long half-life, only a slight activation of its receptors into the signaling pathways might contribute to progressive disturbances, as hypertension and diabetic microvascular disorders (Cimponeriu et al., 2010). From the two receptors, the ETRA, expressed in SMC, has the highest affinity for ET-1, and is involved in the short term 
regulation of SMC and in the long term control of cell growth, adhesion and migration in the vasculature. The ETRB, expressed on both EC and SMC, has a dual function and can cause both vasoconstriction on SMC and vasodilation by the release of endothelial NO (Kalani, 2008; Potenza et al., 2009). The components of ET family are encoded by different genes (Table 3) with a generic name EDN (EDN1, EDN2, EDN3, EDNRA, and EDNRB). All three $E D N$ genes (1 to 3 ) translate a respective amino acid prepropeptide, which is cleaved by one or more dibasic pair-specific endopeptidases to yield big ET. For ET-1, the large precursor is then converted into the mature and active ET-1 by a putative converting enzyme (ECE-1) encoded by the ECE1 gene.

In diabetes, the secreted ET-1 by kidney cells activates its receptors and leads to constriction of renal vessels, inhibition of salt and water reabsorption, and enhanced glomerular proliferation. Correlations between plasma or urinary levels of ET-1 and signs of DN at different stages, as well as a close association between systemic endothelial dysfunction and microalbuminuria have been reported. Elevated ET-1 levels are present before the onset of microalbuminuria in T1DM, and worsen in association with it. In DR, the increased ET-1 levels strongly correlate with the enhanced endothelial permeability and loss of endothelial-mediated vasodilation in the retinal microvasculature (Kalani, 2008; Kankova et al., 2001). In DNP, the ET-1 is a potent vasoconstrictor of vasa nervorum and contributes to the EC abnormalities, when the balance of vasodilatation and vasoconstriction is in the favor of the latter. Moreover, ETA receptors contribute to the development of peripheral neuropathy, while ETB receptors have a protective role (Kalani, 2008; Lam, 2001). Most of the reported findings were for T2DM. A difference in the ET-1 involvement in the development of microvascular disorders in T1DM can not be excluded, knowing that differences in the pathogenesis of microangiopathy between type 1 and type 2 diabetes might exist.

\begin{tabular}{|c|c|c|c|c|c|}
\hline \multicolumn{2}{|c|}{ Gene } & \multicolumn{4}{|c|}{ Protein } \\
\hline \multirow{2}{*}{ Name } & \multirow{2}{*}{ Location } & \multirow{2}{*}{ Name } & \multicolumn{2}{|c|}{ Size } & \multirow{2}{*}{$\begin{array}{l}\text { Subcellular } \\
\text { location }\end{array}$} \\
\hline & & & a.a. & $\mathrm{kDa}$ & \\
\hline EDN1 & $6 \mathrm{p} 24.1$ & ET-1 & 212 & 24.43 & secreted \\
\hline EDN2 & 1p34.2 & ET-2 & 178 & 19.96 & secreted \\
\hline EDN3 & 20q13.2-13.3 & ET-3 & 238 & 25.45 & secreted \\
\hline ECE1 & 1p36.1 & ECE1 & 770 & 87.16 & cell membrane \\
\hline EDNRA & $4 q 31.22$ & ETA receptor & 427 & 48.72 & cell membrane \\
\hline$E D N R B$ & $13 q 22$ & ETB receptor & 442 & 49.64 & cell membrane \\
\hline
\end{tabular}

Table 3. The endothelin family. Source, http://www.genecards.org; a.a., amino acids; kDa, kiloDalton

The EDN1 gene has different polymorphisms including the $-3 A /-4 A$, a -138 insertion/deletion and the $C A / C T$ dinucleotide repeat in promoter, the C8002T or TaqI variant in intron 4, and the Lys198Asn, a G/T polymorphism in exon 5. In EDNRA gene were reported the $-231 \mathrm{~A} / \mathrm{G}$ and $C 1363 T$ variants, while in $E D N R B$ gene the $A 30 G$ polymorphism. Assessments of relationship between variability of plasma concentrations of ET-1 (and big ET-1) and EDN1 polymorphisms (G8002A and $-3 A /-4 A$ ) in patients with chronic heart failure indicated that there was no significant association, suggesting that the genetic 
variants are not risk factors, but plasma ET-1 level influences more the disease severity (Spinarová et al., 2008).

Insufficient data exists regarding the influence of EDN1 polymorphisms on the development of microvascular disorders. In a previous review was shown that EDN1 gene was directly involved in hypertension and polymorphisms in EDNRA were associated with essential hypertension testifying the necessity of a balance within the endothelin system for normal functioning in vascular tissues. Although the importance of ET-1 expression in retinal microvasculature in high glucose was incontrovertible, it appears to be a lack of association between EDN1 and ECE1 polymorphisms and DR (Warpeha \& Chakravarthy, 2003). Interestigly, in T2DM the TT genotype of EDN1 G/T polymorphism was associated with reduce risk of DN (Li et al., 2008).

\section{Genes of renin - Angiotensin system}

Renin-angiotensin system plays a central role in blood pressure regulation and fluid electrolyte balance, being a modulator of vascular tone and structure. RAS components are produced by different organs and are delivered to their site of action by the bloodstream. Angiotensinogen (ANGT) is synthesized primarily by the liver and the released hormone precursor is cleaved by renin enzyme and aspartyl proteinase, to generate angiotensin I (Ang I). The key enzyme of RAS is angiotensin I-converting enzyme (ACE) which converts Ang I to angiotensin II (Ang II) by the release of the terminal His-Leu, when an increase of the vasoconstrictor activity of angiotensin occurs. The Ang II acts through two main receptors, the type 1 Ang II receptor and the type 2 Ang II receptor (Table 4). It is generally believed that type I Ang II receptor is the dominant one in the cardiovascular system, being expressed in different organs including the brain, kidney, heart, skeletal muscle (Abdollahi et al., 2005).

\begin{tabular}{|c|c|c|c|c|c|}
\hline \multicolumn{2}{|l|}{ Gene } & \multicolumn{4}{|l|}{ Protein } \\
\hline \multirow[t]{2}{*}{ Name } & \multirow[t]{2}{*}{ Location } & \multirow[t]{2}{*}{ Name } & \multicolumn{2}{|l|}{ Size } & \multirow[t]{2}{*}{ Subcellular location } \\
\hline & & & a.a. & $\mathrm{kDa}$ & \\
\hline$A C E$ & 17q23.3 & ACE & 1306 & 149.72 & $\begin{array}{l}\text { secreted and } \\
\text { cell membrane }\end{array}$ \\
\hline ACE2 & Xp22 & ACE2 & 805 & 92.46 & $\begin{array}{l}\text { secreted and } \\
\text { cell membrane }\end{array}$ \\
\hline$A G T$ & $1 q 42-q 43$ & ANGT & 485 & 53.15 & secreted \\
\hline AGTR1 & $3 q 24$ & $\begin{array}{l}\text { Type } 1 \text { Ang II } \\
\text { receptor }\end{array}$ & 359 & 41.06 & cell membrane \\
\hline AGTR2 & Xq22-q23 & $\begin{array}{l}\text { Type } 2 \text { Ang II } \\
\text { receptor }\end{array}$ & 363 & 41.18 & cell membrane \\
\hline
\end{tabular}

Table 4. Renin-angiotensin system. Source, http:/ / www.genecards.org; a. a., amino acids; kDa, kiloDalton

The RAS effects are primarily mediated by Ang II, a trophic hormone, which acts either directly on tissues, including vascular remodeling and inflammation or indirectly on NO bioavailability and its consequences (Chung et al., 2010; Ringel et al., 1997). In distinct local organs (brain, kidney, eye, vessel wall, heart) RAS regulatory mechanisms and function are 
different, so the Ang II actions may be modulated by a specific physiological process of a given tissue system. A variety of stimuli, including hyperglycemia, hypertension, sodium intake, inflammation modulate the expression of the tissue RAS components in pathophysiological states, and chronic production of Ang II may proceed remodeling and restructuring in various cardiovascular organs (Conen et al., 2008).

Discovery of ACE homologue, angiotensin I-converting enzyme 2 (ACE2) increased the complexity of RAS. ACE2 is predominantly expressed in endothelium of different tissues (i.e. kidney), although its distribution is much less widespread than ACE. The enzyme hydrolyses different peptides, including Ang I and Ang II, and is implicated in hypertension, diabetic nephropathy, and cardiovascular disease (Fröjdö et al., 2005). ACE2 seems to act as a negative regulator of the RAS, counterbalancing the function of ACE thus promoting vasodilation (Giunti et al., 2006).

RAS is a causative factor in diabetic microvascular complications inducing a variety of tissue responses including vasoconstriction, inflammation, oxidative stress, cell hypertrophy and proliferation, angiogenesis and fibrosis. Most of previous reports showed the RAS role in the initiation and progression of diabetic nephropathy. In the kidney, Ang II affects renal hemodynamics, tubular transport and stimulates growth and proto-oncogenes in various renal cell types. Increased production of angiotensin II within nephrons and their vasculature could participate in the local renal injury through both hemodynamic and nonhemodynamic actions and is a well-established factor promoting renal damage (Gumprecht et al., 2000). Because the low conversion of Ang I in the kidney, it has been proposed that the plasma ACE circulating through the kidney is an important contributor but yet a limiting factor in angiotensin II production within the renal circulation (Marre et al., 1997).

On the other hand, ACE2 which has a similar distribution to ACE, being largely localized in renal tubules, when is downregulated, as in diabetes-associated kidney disease, leads to an increase of tubular Ang II, which, in turn, may promote tubulointerstitial fibrosis. In early phases of diabetes in the absence of renal injury, it was suggested that ACE2 expression is increased, and in compensation the ACE was inhibited preventing the diabetes associated renal disease. These findings suggest that ACE inhibition may confer a renoprotective effect (Giunti et al., 2006). In diabetes, damage to the retina occurs in the vasculature, neurons and glia resulting in pathological angiogenesis, vascular leakage and a loss in retinal function. All components of RAS have been identified in the retina and iris and it is likely that the local rather than systemic RAS is involved in ocular neovascularization. It was reported that the RAS components were upregulated in DR.

\subsection{ACE gene}

ACE, the main enzyme of RAS, is encoding by the ACE gene, composed of 26 exons, and span a total of $21 \mathrm{~kb}$ (Table 4). The genetic structure is made up of three ancestral regions, and two intragenic ancestral recombination breakpoints flank the gene region (Boright et al., 2005). Several polymorphisms have been reported in ACE gene. The two biallelic SNPs within and flanking the gene are in strong linkage disequilibrium with each other (Boright et al., 2005). The most extensively studied polymorphism was insertion/deletion of a 287bp Alu repeat in intron 16 (rs179975; Ins/Del; I/D) being considered a "reference" polymorphism (Hadjadj et al., 2007; Mooyaart et al., 2011). ACE activity is significantly connected with genetic variations at the ACE gene. The $r s 179975$ accounts for $44 \%$ of the interindividual variability of plasma ACE levels, and high ACE values were found among 
subjects with $D D$ genotype. Other report showed that about $24 \%$ of the variance in the ACE activity was attributed to other ACE polymorphisms rs4343, rs495828 and rs8176746 (Chung et al., 2010).

Some reports indicated in Caucasian T1DM patients that ACE I/D was not associated with the development of persistent microalbuminuria, or overt DN (Möllsten et al., 2008; Ringel et al., 1997; Tarnow et al., 2000). A protective role to the homozygosity for the insertion $(I / I)$ of $A C E$ gene in the DN development was attributed. With the increase of duration of diabetes it seems that the ACE I/I genotype is associated with longevity and survival in T1DM patients but not particularly in DN subjects (Boright et al., 2005). Other reports indicated that the $A C E D / D$ genotype was more frequent in patients with $\mathrm{DN}$ and the presence of the $A C E D / D$ or $I / D$ genotypes was associated with a faster rate of the decline of the renal function, suggesting that the ACE $D$ allele represents an increased risk for both the onset and the progression of DN (Costacou et al., 2006; Gumprecht et al., 2000; Ng et al., 2005; Nosikov, 2004).

From other $A C E$ polymorphisms studied for the association with $\mathrm{DN}$, it was reported that the G7831A (Nosikov, 2004), rs4293 and rs4309 (Currie et al., 2010) were not associate, while rs1800764 and rs9896208 (Boright et al., 2005) were associate with the disease. Regarding the rs1800764 (T/C) variant, patients who carried the wild-type $T$ allele were at lower risk for persistent microalbuminuria or severe $\mathrm{DN}$, while heterozygous patients $(T / C)$ had a higher risk for severe nephropathy, suggesting a genotype rather than an allele effect (Hadjadj et al., 2007). The reported haplotypic structure of $A C E$ was considered to contain four polymorphisms $r s 4311, r s 4366, r s 1244978$ and rs1800764 (Hadjadj et al., 2007). Interestingly, the homozygosity for the common haplotype that carries the ACE I allele, as TIC haplotype, corresponding to the wild type alleles of $r s 1800764, I / D$ and $r s 9896208$, respectively was associated with lower risk for development of severe DN. This finding provides a strong evidence that genetic variation at the $A C E$ gene is associated with the development of DN (Boright et al., 2005). On the other hand it was reported that a haplotype containing the rare allele the $D$ of $I / D$ variant, $G$ of $r s 4366$ and $G$ of $r s 12449782$ was associated with a higher risk for DN (Hadjadj et al., 2007).

Diabetic nephropathy is rarely diagnosed using invasive kidney biopsies and generally in genetic studies DN patients were those who presented albuminuria. Conflicting results of the gene association with the disease might occur, in addition, from the fact that a substantial number of subjects were classified as having DN but actually have nondiabetic kidney disease instead. Certain investigators have proposed that DN cases should be required to have diabetic retinopathy as well. From 1994 up to 2006 there were numbers of reports analyzing T1DM patients with DN having in addition various proportion of DR ( $\mathrm{Ng}$ et al., 2008). The relationship between ACE polymorphisms and DR was less studied. Most reports found no association of ACE I/D with the development of any form of DR in adult or younger Type 1 diabetic patients (Abhary et al., 2009a; Zhou \& Yang, 2010). Other data showed that in patients with DR, the severity of DR was associated with ACE I/D polymorphism (Marre et al., 1997). While nearly all T1DM individuals can develop DR or DPN, only a fraction of the subjects develops DN. So, it is hard to determine whether any observed association between ACE I/D and DN or DR or combined DN/DR truly exists. Including DR in the identification of potential genetic factors for the microvascular disorders might help, considering that some patients manifest a joint retinal-renal phenotype ( $\mathrm{Ng}$ et al., 2008).

Taken together, these data indicate that the $I / D$ variant of $A C E$ gene, considered a "reference" polymorphism, responsible, at least in part, for the interindividual variability of plasma ACE levels, is associated with the faster rate decline of renal function, particularly in patients with a less than 10 years of diabetes duration, and the ACE D allele represents an 
increased risk for both the onset and the progression of DN. These findings were confirmed by multiple, independent studies. This potential genetic factor for $\mathrm{DN}$ development might be correlated also with DR, suggesting its involvement in the diabetic complex phenotype.

\subsection{Other RAS genes}

ACE2 has approximately $40 \%$ homology with ACE sharing $42 \%$ identity with the catalytic domain of somatic ACE, and promotes vasodilatation counterbalancing the ACE effect. The ACE2 gene consists of 18 exons is stable and conserved, indicating, that the genetic effect is small, and it intertwines and functions in concert with many other genes, suggesting the presence of epistatic effects (Fröjdö et al., 2005; Zhou \& Yang, 2010). Data of genes for other RAS components are presented in Table 4. From the variants (rs714205; rs879922; rs1978124; rs2023802; rs2048684; rs2074192; rs2285666; rs4646188; rs5978731) reported few studies implied genomic analyses of diabetes microvascular disorders. None of the studied polymorphisms were associated with DR (Currie et al., 2010; Fröjdö et al., 2005). An increased in ACE2 expression in early phases of diabetes in the absence of renal injury was reported (Giunti et al., 2006).

Angiotensinogen gene has more than 30 genetic polymorphisms as reported in different studies, M24686, C1015T (T174M; rs4762; Thr/Met), T1198C (M235T; rs699; Met/Thr), A1237G (Tyr/Cys), A1204C (A-20C; rs5050), G1218A (G-6A; rs5051). The most studied polymorphism in relation with diabetic microvascular disorders was rs699 in exon 2 when a $T$ to $C$ base substitution at position 702 take place, with the consequent replacement of methionine 235 with threonine. A relationship between the $T$ allele of $r s 699$ and increased plasma Ang II levels was reported only in male subjects and may account for no more than 5\% of ANGT variability (Marre et al., 1997, Ruggenenti et al., 2008). Reports on the association of AGT rs699 and the development of DN in adults with T1DM showed conflicting results; some finding indicated no association (Chowdhury et al., 1996; Currie et al., 2010; Hadjadj et al., 2001; Möllsten et al., 2008; Nosikov, 2004; Ringel et al., 1997; Tarnow et al., 2000), and others suggested that this variant contribute to the increased risk for chronic renal failure (Gumprecht et al., 2000). In young T1DM subjects, the TT genotype of AGT rs699 had a fourfold increased risk for persistent microalbuminuria, suggesting that this variant is a strong predictor for early stage of DN (Gallego et al., 2008). One report analyzed AGT T174M in relation with $\mathrm{DN}$, and the findings indicated no association with the disease (Nosikov, 2004). There were no reports indicated a significant relationship between AGT rs699 and DR, but in patients with incipient diabetic renal failure the T allele of AGT rs699 was associated with DR. In these patients interaction between the $D$ allele of $A C E I / D$ and the $T$ allele of $A G T$ rs699 tended towards protection against DN (Van Ittersum et al., 2000). Oppose, other study indicated that the same interaction increases risk for DN in patients $\mathrm{cu}$ DR (Marre et al., 1997). All these data suggest that extensive studies has to be done in large number of T1DM patients with combined DN and DR vs only one microvascular disorder for the epistatic interactions between $A C E$ and AGT polymorphisms and their relationship of the disease.

In AGTR1 gene were identify a variety of polymorphisms AF245699, A49954G (rs5183; A1878G; Pro/Pro), A50058C (rs5186; A1166C), T4955A (rs275651), T5052G (rs275652), C5245T (rs1492078), A1062G, T573C, G1517T (Ruggenenti et al., 2008). Reports on the relationship of AGTR1 polymorphisms with DN showed that the AA genotype of $r s 5186$ was independently associated with overt $\mathrm{DN}$, being with a threefold increase in the risk for the disease 
compared to AC and CC genotypes (Möllsten et al., 2008). The treatment with renoprotective antihypertensive (losartan) for slowing down the progression of diabetic glomerulopathy reduced significantly albuminuria, systolic and diastolic blood pressure in the $A$ allele vs $C$ allele carriers of $r s 5186$ polymorphism (Dragović et al., 2010). Oppose, the rs5186 of AGTR1 was found not associated with DN in other reports (Gallego et al., 2008; Nosikov, 2004; Tarnow et al., 2000). There are no data on the influence of AGTR1 gene polymorphism on the development of DR or DPN. For AGTR2 gene have been identified few variants, U20860 (T3786C; rs5192; Ala/Ala), G1675A (rs1403543), G4297T (rs5193), A4303G (rs5194) but there are no reports showing the involvement of one polymorphism with T1DM microvascular disorders.

Although the prognosis of patients with DN has improved, the decline in the GFR still varies among T1DM patients. The nongenetic risk factors (elevated blood pressure, albuminuria, and $\mathrm{HbA}_{1 \mathrm{c}}$ ) for excessive loss of GFR, explain only approximately 30 to $50 \%$ of the decrease, and the epistatic interactions between ACE, ACE2, AGT, AGTR1 or AGTR2 polymorphisms in the RAS, a concept previously suggested (Jacobsen et al., 2003) might represent a risk factor for DN. It was reported that despite the non-significant effects of a single-gene on DN progression, a combined genetic variable including the potential "bad" alleles ( $D$ of $A C E$ I/D, M of AGT rs699, and A of AGTR1 rs5186) represent a risk factor for the disease (Jacobsen et al., 2003). These data suggest that in some conditions a single gene variant may cause appreciable phenotypic changes only upon combination with other polymorphisms, having additional or synergistic effects on the same metabolic pathways (Ruggenenti et al., 2008). Oppose, other data showed that DN was not influenced by the epistatic interactions between the polymorphisms of the RAS genes. (Gallego et al., 2008; Tarnow et al., 2000)

\section{Conclusion}

All over the world, the incidence of type 1 diabetes continue to be much higher than in general population. Despite major progresses done in the recent years to identify candidate genes involved in the development of diabetic microvascular complications, there are still controversial results and insufficient knowledge in the literature, although a variety of genomic strategies were applied. While the degree of metabolic control remains the main risk factor for the development of diabetic chronic complications, the genetic risk factors, common for retinopathy, neuropathy, and renal disease, or specific for each of them, are important contributors to the disease severity. Discrepancies between reported data are due to differences in the genetic background between studied populations, small sample sizes, insufficient phenotype description, genotyping procedures, individual gene polymorphism assessment, few numbers of loci included in the studies, and requirement of interaction analysis between gene-gene variants. Genetic prediction and use of individual aetiological processes, as well as the translation of recent molecular knowledge into potential therapeutic agents will contribute selectively to the preventive and therapeutic interventions in this complex disease.

\section{Acknowledgment}

This work was financially supported by grants from the Romanian Academy, Ministry of Education and Research and by an EFSD New Horizons Grant. 


\section{References}

Abdollahi, MR., Gaunt, TR., Syddall, HE., Cooper, C., Phillips, DIW., Ye, S. \& Day, INM. (2005) Angiotensin II type I receptor gene polymorphism: anthropometric and metabolic syndrome traits. Journal Medical Genetics, Vol. 42, No. 5, (May), pp. 396401, ISSN 0022-2593.

Abhary, S., Hewitt, A., Burdon, K. \& Craig, J. (2009a). A systematic meta-analysis of genetic association studies for diabetic retinopathy. Diabetes, Vol. 58, No. 9, (September), pp. 2137-2147, ISSN 0012-1797.

Abhary, S., Burdon, KP., Gupta, A., Lake, S., Selva, D., Petrovsky, N. \& Craig, JE. (2009b) Common sequence variation in the VEGFA gene predicts risk of diabetic retinopathy. Investigative Ophthalmology \& Vissual Science, Vol. 50, No. 12, (December), pp. 5552-5558, ISSN 0146-0404.

Akerblom, HK., Vaarala, O., Hyöty, H., Ilonen, J. \& Knip, M. (2002) Environmental factors in the etiology of type 1 diabetes. American Journal of Medical Genetics, Part A, Vol. 115, No. 1, (March), pp. 18-29, ISSN 0148-7299.

Amos, A., McCarty, D. \& Zimmet, P. (1997) The rising global burden of diabetes and its complications: estimates and projections to the year 2010. Diabetic Medicine, Vol. 14, Suppl. 5, (December), pp. S1-S85, ISSN 0742-3071.

Bazzaz, JT., Amoli, MM., Pravica, V., Chandrasecaran, R., Boulton, AJ., Larijani, B. \& Hutchinson, IV. (2010) eNOS gene polymorphism association with retinopathy in type 1 diabetes. Ophthalmic Genetics, Vol. 31, No. 3, (September), pp. 103-107, ISSN 1381-6810.

Boright, AP., Paterson, AD., Mirea, L., Bull, SB., Mowjoodi, A., Scherer, SW., Zinman, B. \& the DCCT/EDIC Research Group. (2005) Genetic variation at the ACE gene is associated with persistent microalbuminuria and severe nephropathy in type 1 diabetes. The DCCT/EDIC Genetics Study. Diabetes, Vol. 54, No. 6, (June), pp. 12381244, ISSN 0012-1797.

Bottazzo, GF., Mann, JI., Thorogood, M., Baum, JD. \& Doniach, D. (1978) Autoimmunity in juvenile diabetics and their families. British Medical Journal, Vol. 2, No. 6131, (July), pp. 165-168, ISSN 0007-1447.

Brouet, A., Sonveaux, P., Dessy, C., Balligand, JL. \& Feron, O. (2001) Hsp90 ensures the transition from the early $\mathrm{Ca} 2+-$ dependent to the late phosphorylation-dependent activation of the endothelial nitricoxide synthase in vascular endothelial growth factor-exposed endothelial cells. The Journal of Biological Chemistry, Vol. 276, No. 35, (August), pp. 32663-32669, ISSN 0021-9258.

Brownlee, M. (2005) The pathobiology of diabetic complications. A unifying mechanism. Diabetes, Vol. 54, No. 6, (June), pp. 1615-1625, ISSN 0012-1797.

Cellek, S. (2004) Point of NO return for nitrergic nerves in diabetes: a new insight into diabetic complications. Current Pharmaceutical Design, Vol. 10, No. 29, pp. 36833695, ISSN 1381-6128.

Chandra, D., Jackson, EB., Ramana, KV., Kelley, R., Srivastava, SK. \& Bhatnagar, A. (2002) Nitric oxide prevents aldose reductase activation and sorbitol accumulation during diabetes. Diabetes, Vol. 51, No. 10, (October), pp. 3095-3101, ISSN 0012-1797.

Chen, Y., Huang, H., Zhou, J., Doumatey, A., Lashley, K., Chen, G., Agyenim-Boateng, K., Eghan, BA., Acheampong, J., Fasanmade, O., Johnson, T., Akinsola, FB., Okafor, G., 
Oli, J., Ezepue, F., Amoah, A., Akafo, S., Adeyemo, A. \& Rotimi CN. (2007) Polymorphism of the endothelial nitric oxide synthase gene is associated with diabetic retinopathy in a cohort of West Africans. Molecular Vision, Vol. 13, (16 November), pp. 2142-2147, ISSN 1090-0535.

Chiarelli, F., Cipollone, F., Romano, F., Tumini, S., Costantini, F., di Ricco, L., Pomilio, M., Pierdomenico, SD., Marini, M., Cuccurullo, F. \& Mezzetti, A. (2000) Increased circulating nitric oxide in young patients with type 1 diabetes and persistent microalbuminuria: relation to glomerular hyperfiltration. Diabetes, Vol. 49, No. 7, (July), pp. 1258-1263, ISSN 0012-1797.

Chowdhury, TA., Dronsfield, MJ., Kumar, S., Gough, SLC., Gibson, SP., Khatoon, A., MacDonald, F., Rowe, BR., Dunger DB. \& Dean, JD. (1996) Examination of two genetic polymorphisms within the renin-angiotensin system: no evidence for an association with nephropathy in IDDM. Diabetologia, Vol. 39, No. 9, (September), pp. 1108-1114, ISSN0012-186X.

Chung, C-M., Wang, R-Y., Chen, J-W., Fann, CSJ., Leu, H-B., Ho, H-Y., Ting, C-T., Lin, T-H., Sheu, S-H., Tsai, W-C., Chen, J-H., Jong, Y-S., Lin, S-J., Chen, Y-T. \& Pan, W-H. (2010) A genome-wide association study identifies new loci for ACE activity: potential implications for response to ACE inhibitor. The Pharmacogenomics Journal, Vol. 10, No. 6, (December), pp. 537-544, ISSN 1470-269X/10.

Cimponeriu, D., Crăciun, A-M., Apostol, P., Radu, I., Guja, C. \& Cheța, D. (2010) The genetic background of diabetes chronic complications. In: Genetics of diabetes. The Truth Unveiled, D. Cheța (Ed), 193-334, Academia Romana \& S. Karger AG, ISBN 978-97327-1901-5, Bucharest/Basel, Romania.

Concannon, P., Rich, SS. \& Nepom, GT. (2009) Genetics of type 1A diabetes. The New England Journal of Medicine, Vol. 360, No. 16, (April), pp. 1646-1654, ISSN 0028-4793.

Conen, D., Glynn, RJ., Buring, JE., Ridker, PM. \& Zee, RYL. (2008) Association of reninangiotensin and endothelial nitric oxide synthase gene polymorphisms with blood pressure progression and incident hypertension: prospective cohort study. Journal of Hypertension, Vol. 26, No. 9, (September), pp. 1780-1786, ISSN 0263-6352.

Costacou, T., Chang, Y., Ferrell, RE. \& Orchard, TJ. (2006) Identifying genetic susceptibilities to diabetes-related complications among individuals at low risk of complications: An application of tree-structured survival analysis. American Journal of Epidemiology, Vol. 164, No. 9, (November), pp. 862-872, ISSN 0002-9262.

Currie, D., McKnight, AJ., Patterson, CC., Sadlier, DM. \& Maxwell, AP. (2010) The UK Warren/GoKinD study group investigation of ACE, ACE2 and AGTR1 genes for association with nephropathy in Type 1 diabetes mellitus. Diabetic Medicine, Vol. 27, No. 10, (October), pp. 1188-1194, ISSN 0742-3071.

DCCT Research Group. (1993) The effect of intensive treatment of diabetes on the development and progression of long-term complications in insulin-dependent diabetes mellitus. The Diabetes Control and Complications Trial Research Group. The New England Journal of Medicine, Vol. 329, No. 14, (September), pp. 977-986, ISSN 0028-4793.

DCCT/EDIC Research Group, Nathan, DM., Zinman, B., Cleary, PA., Backlund, JY., Genuth, S., Miller, R. \& Orchard, TJ. (2009) Modern-day clinical course of type 1 diabetes mellitus after 30 years' duration: the diabetes control and complications 
trial/epidemiology of diabetes interventions and complications and Pittsburgh epidemiology of diabetes complications experience (1983-2005). Archives of Internal Medicine, Vol. 169, No. 14, (July), pp. 1307-1316, ISSN 0003-9926.

Degen, B., Schmidt, S. \& Ritz, E. (2001) A polymorphism in the gene for the endothelial nitric oxide synthase and diabetic nephropathy. Nephrology Dialysis Transplantation, Vol. 16, No. 1, (January), pp. 185-198, ISSN 0931-0509.

DIAMOND Project Group. (2006) Incidence and trends of childhood Type 1 diabetes worldwide 1990-1999. Diabetic Medicine, Vol. 23, No. 8, (August), pp. 857-866, ISSN 0742-3071.

Doria, A. (2010) Genetics of diabetes complications. Current Diabetes Reports, Vol. 10, No. 6, (December), pp. 467-475, ISSN 1534-4827.

Dragović, T., Ajdinović, B., Hrvacević, R., Ilić, V., Magić, Z., Andelković, Z. \& Kocev, N. (2010) Angiotensin II type 1 receptor gene polymorphism could influence renoprotective response to losartan treatment in type 1 diabetic patients with high urinary albumin excretion rate. Vojnosanitetski pregled. Military-medical and pharmaceutical review, Vol. 67, No. 4, (May), pp. 273-278, ISSN 0042-8450.

Eisenbarth, GS. (1986) Type 1 diabetes: a chronic autoimmune disease. The New England Journal of Medicine, Vol. 314, No. 21, (May), pp. 1360-1368, ISSN 0028-4793.

Erbs, S., Baither, Y., Linke, A., Adams, V., Shu, Y., Lenk, K., Gielen, S., Dilz, R., Schuler, G. \& Hambrecht, R. (2003) Promoter but not exon 7 polymorphism of endothelial nitric oxide synthase a Vects training induced correction of endothelial dysfunction. Arteriosclerosis, Thrombosis, and Vascular Biology, Vol. 23, No. 10, (October), pp. 1814-1819, ISSN 1079-5642.

EURODIAB IDDM Complications Study Group. (1994) Microvascular and acute complications in insulin dependent diabetes mellitus: the EURODIAB IDDM Complications Study. Diabetologia, Vol. 37, No. 11, (November), pp. 278-285, ISSN 0012-186X.

Frank, RN. (2004) Diabetic retinopathy. The New England Journal of Medicine, Vol. 350, No. 1, (January), pp. 48-58, ISSN 0028-4793.

Freedman, BI., Yu, H., Anderson, PJ., Roh, BH., Rich, SS. \& Bowden, DW. (2000) Genetic analysis of nitric oxide and endothelin in end-stage renal disease. Nephrology Dialysis Transplantation, Vol. 15, No. 11, (November), pp.1794-800, ISSN 0931-0509.

Freedman, BI., Bostrom, M., Daeihagh, P. \& Bowden, DW. (2007) Genetic factors in diabetic nephropathy. Clinical Journal of the American Society of Nephrology, Vol. 2, No. 6, (November), pp. 1306-1316, ISSN 1555-9041.

Fröjdö, S., Sjölind, L., Parkkonen, M., Mäkinen, V-P., Kilpikari, R., Pettersson-Fernholm, K., Forsblom, C., Fagerudd, J., Tikellis, C., Cooper, ME., Wessman, M., Groop, P-H. \& FinnDiane Study Group. (2005) Polymorphisms in the gene encoding angiotensin I converting enzyme 2 and diabetic nephropathy. Diabetologia, Vol. 48, No. 11, (November), pp. 2278-2281, ISSN 0012-186X.

Gallego, PH., Shephard, N., Bulsara, MK., van Bockxmeere, FM., Powell, BL., Beilby, JP., Arscott, G., Le Page, M., Palmer, LJ., Davis, EA., Jones, TW. \& Choong, CSY. (2008) Angiotensinogen gene T235 variant: a marker for the development of persistent microalbuminuria in children and adolescents with type 1 diabetes mellitus. Journal of Diabetes and Its Complications, Vol. 22, (May - June), pp. 191- 198, ISSN 1056-8727. 
Gepts, W. (1965) Pathologic anatomy of the pancreas in juvenile diabetes mellitus. Diabetes, Vol. 14, No. 10, (October), pp. 619-633, ISSN 0012-1797.

Groop, PH., Thomas, MC., Moran, JL., Wadèn, J., Thorn, LM., Mäkinen, VP., RosengårdBärlund, M., Saraheimo, M., Hietala, K., Heikkilä, O., Forsblom, C. \& FinnDiane Study Group. (2009) The presence and severity of chronic kidney disease predicts all-cause mortality in type 1 diabetes. Diabetes, Vol. 58, No. 7, (July), pp. 1651-1658, ISSN 0012-1797.

Gumprecht, J., Zychma, MJ., Grzeszczak, W., Zukowska-Szczechowska, E. \& End-Stage Renal Disease study group. (2000) Angiotensin I-converting enzyme gene insertion/deletion and angiotensinogen M235T polymorphisms: Risk of chronic renal failure. Kidney International, Vol. 58, No. 2, (August), pp. 513-519, ISSN 00852538.

Giunti, S., Barit, D. \& Cooper, ME. (2006) Mechanisms of diabetic nephropathy: Role of hypertension. Hypertension, Vol. 48, No. 4, (October), pp. 519-526, ISSN 0194-911X.

Hadi, HA. \& Suwaidi, JA. (2007) Endothelial dysfunction in diabetes mellitus. Vascular Health and Risk Management, Vol. 3, No. 6, (December), pp. 853-876, ISSN 1176-6344.

Hadjadj, S., Belloum, R., Bouhanick, B., Gallois, Y., Guilloteau, G., Chatellier, G., AlhencGelas, F. \& Marre, M. (2001) Prognostic value of angiotensin-I converting enzyme I/D polymorphism for nephropathy in type 1 diabetes mellitus: A prospective study. Journal of American Society of Nephrology, Vol. 12, No. 3, (March), pp. 541549, ISSN 1046-6673.

Hadjadj, S., Tarnow, L., Forsblom, C., Kazeem, G., Marre, M., Groop, PH., Parving, HH., Cambien, F., Tregouet, DA., Gut, IG., Theva, A., Gauguier, D., Farrall, M., Cox, R., Matsuda, F., Lathrop, M. \& Hager-Vionnet, N. (2007) Association between angiotensin-converting enzyme gene polymorphisms and diabetic nephropathy: Case-control, haplotype, and family-based study in three European populations. Journal of American Society of Nephrology, Vol. 18, No. 4, (April), pp. 1284-1291, ISSN 1046-6673.

Heltianu, C., Manea, SA., Guja, C., Mihai, C. \& Ionescu-Tirgoviste, C. (2008). Correlation of low molecular weight advanced glycation end products and nitric oxide metabolites with chronic complications in type 1 diabetic patients. Central European Journal of Biology, Vol. 3, No. 3, (September), pp. 243-249, ISSN 1895-104X.

Heltianu, C., Manea, SA., Guja, C., Robciuc, A. \& Ionescu-Tirgoviste, C. (2009) Polymorphism in exon 7 of the endothelial nitric oxide synthase gene is associated with low incidence of microvascular damage in type 1 diabetic neuropathy. Central European Journal of Biology, Vol. 4, No. 4, (December), pp. 521-5273, ISSN 1895$104 X$.

International Diabetes Federation. (2009). IDF Diabetes Atlas (4th), (May), International Diabetes Federation, ISBN 13: 978-2-930229-71-3, Brussels, Belgium.

Jacobsen, P., Tarnow, L., Carstensen, B., Hovind, P., Poirier, O. \& Parving, H-H. (2003) Genetic variation in the renin-angiotensin system and progression of diabetic nephropathy. Journal of American Society of Nephrology, Vol. 14, No. 11, (November), pp. 2843-2850, ISSN 1533-3450.

Johannesen, J., Pociot, F., Kristiansen, OP., Karlsen, AE., Nerup, J., DIEGG. \& DSGD. (2000a) No evidence for linkage in the promoter region of the inducible nitric oxide 
synthase gene (NOS2) in a Danish type 1 diabetes population. Genes and Immunity, Vol. 1, No. 6, (August), pp. 362-366, ISSN 1466-4879.

Johannesen, J., Tarnow, L., Parving, HH., Nerup, J. \& Pociot, F. (2000b) CCTTT-repeat polymorphism in the human NOS2-promoter confers low risk of diabetic nephropathy in type 1 diabetic patients. Diabetes Care, Vol. 23, No. 4, (April), pp. 560-562, ISSN 0149-5992.

Johannesen, J., Pie, A., Pociot, F., Kristiansen, OP., Karlsen, AE. \& Nerup, J. (2001) Linkage of the human inducible nitric oxide synthase gene to type 1 diabetes. The Journal Clinical Endocrinology and Metabolism, Vol. 86, No. 6, (June), pp. 2792-2796, ISSN 0021-972X.

Kalani, M. (2008) The importance of endothelin-1 for microvascular dysfunction in diabetes. Vascular Health and Risk Management, Vol. 4, No. 5, (May), pp. 1061-1068, ISSN 1178-2048.

Kankova, K., Muzik, J., Karaskova, J., Beranek, M., Hajek, D., Znojil, V., Vlkova, E. \& Vacha, J. (2001) Duration of non-insulin-dependent diabetes mellitus and the TNF-B NcoI genotype as predictive factors in proliferative diabetic retinopathy. Ophthalmologica, Vol. 215, No. 4, (July - August), pp. 294-298, ISSN 0030-3755.

Keenan, HA., Costacou, T., Sun, JK., Doria, A., Cavellerano, J., Coney, J., Orchard, TJ., Aiello, LP. \& King, GL. (2007) Clinical factors associated with resistance to microvascular complications in diabetic patients of extreme disease duration: the 50-year medalist study. Diabetes Care, Vol. 30, No. 8, (August), pp. 1995-1997, ISSN 0149-5992.

Kempler, P. (2002) Pathomorphology and pathomechanism. In: Neuropathies. Pathomechanism, clinical presentation, diagnosis, therapy. P. Kempler (Ed.), 21-39, Springer Scientific Publisher, ISBN 963-699-166-9, Budapest, Hungary.

Lam, H-C. (2001) Role of endothelin in diabetic vascular complications. Endocrine, Vol. 14, No. 3, (April), pp. 277-284, ISSN 0969-711X.

Li, C., Hu, Z., Liu, Z., Wang, L-E., Gershenwald, JE., Lee, JE., Prieto, VG., Duvic, M., Grimm, EA. \& Wei, Q. (2007) Polymorphisms of the neuronal and inducible nitric oxide synthase genes and the risk of cutaneous melanoma. Cancer, Vol. 109, No. 8, (April), pp. 1570-1578, ISSN 0008-543X.

Li, H., Louey, JWC., Choy, KW, Liu, DTL., Chan, WM., Chan, YM., Fung, NSK., Fan, BJ., Baum, L., Chan, JCN., Lam, DSC. \& Pang, CP. (2008) EDN1 Lys198Asn is associated with diabetic retinopathy in type 2 diabetes. Molecular Vision, Vol. 14, (15 September), pp. 1698-1704, ISSN 1090-0535.

Maahs, DM., West, NA., Lawrence, JM. \& Mayer-Davis, EJ. (2010) Epidemiology of type 1 diabetes. Endocrinology Metabolism Clinics of North America, Vol. 39, No. 3, (September), pp. 481-497, ISSN 0889-8529.

Mamoulakis, D., Bitsori, M., Galanakis, E., Vazgiourakis, V., Panierakis, C. \& Goulielmos, GN. (2009) Intron 4 polymorphism of the endothelial nitric oxide synthase eNOS gene and early microangiopathy in type 1 diabetes. International Journal of Immunogenetics, Vol. 36, No. 3, (June), pp. 153-157, ISSN 1744-3121.

Marre, M., Jeunemaitre, X., Gallois, Y., Rodier, M., Chatellier, G., Sert, C., Dusselier, L., Kahal, Z., Chaillous, L., Halimi, S., Muller, A., Sackmann, H., Bauduceau, B., Bled, F., Passa, P. \& Alhenc-Gelas, F. (1997) Contribution of genetic polymorphism in the renin-angiotensin system to the development of renal complications in insulin- 
dependent diabetes. Génétique de la néphropathie diabétique (GENEDIAB) study group. The Journal of Clinical Investigation, Vol. 99, No. 7, (April), pp. 1585-1595, ISSN 0021-9738.

Melikian, N., Seddon, MD., Casadei, B., Chowienczyk, PJ. \& Shah, AM. (2009) Neuronal nitric oxide synthase and human vascular regulation. Trends in Cardiovascular Medicine, Vol. 19, No. 8, (November), pp. 256-262, ISSN 1050-1738.

Mogensen, CE. (2000) Definition of diabetic renal disease in insulin dependent diabetes mellitus, based on renal function tests. In: The Kidney and Hypertension in Diabetes Mellitus. CE. Mogensen (Ed), 13-29, Kluwer Academic Publishers, ISBN 9780792379010, ISBN 0792379012, Boston, USA.

Möllsten, A., Kockum, I., Svensson, M., Rudberg, S., Ugarph-Morawski, A., Brismar, K., Eriksson, JW. \& Dahlquist, G. (2008) The effect of polymorphisms in the reninangiotensin-aldosterone system on diabetic nephropathy risk. Journal of Diabetes and Its Complications, Vol. 22, No. 6, (November - December), pp. 377-383, ISSN 1056-8727.

Möllsten, A., Lajer, M., Jorsal, A. \& Tarnow, L. (2009) The endothelial nitric oxide synthase gene and risk of diabetic nephropathy and development of cardiovascular disease in type 1 diabetes. Molecular Genetics and Metabolism, Vol. 97, No. 1, (May), pp. 8084, ISSN 1096-7192.

Mooyaart, AL., Valk, EJJ., van Es, LA., Bruijn, JA., de Heer, E., Freedman, BI., Dekkers, OM. \& Baelde, HJ. (2011) Genetic associations in diabetic nephropathy: a meta-analysis. Diabetologia, Vol. 54, No. 3, (March), pp. 544-553, ISSN 0012-186X.

Morahan, G., Mehta, M., James, I., Chen, WM., Akolkar, B., Erlich, HA., Hilner, JE., Julier, C., Nerup, J., Nierras, C., Pociot, F., Todd, JA., Rich, SS. \& Type 1 Diabetes Genetics Consortium. (2011) Tests for genetic interactions in type 1 diabetes: Linkage and stratification analyses of 4,422 affected sib-pairs. Diabetes, Vol. 60, No. 3, (March), pp. 1030-1040, ISSN 0012-1797.

Ned, RM., Yesupriya, A., Imperatore, G., Smelser, DT., Moonesinghe, R., Chang, M-H. \& Dowling, NF. (2010) Inflammation gene variants and susceptibility to albuminuria in the U.S. population: analysis in the Third National Health and Nutrition Examination Survey (NHANES III), 1991-1994. BMC Medical Genetics, Vol. 11, (5 November), pp. 155-170, ISSN 1471-2350.

Ng, DPK., Tai, BC., Koh, D., Tan, KW.\& Chia, KS. (2005) Angiotensin-I converting enzyme insertion/deletion polymorphism and its association with diabetic nephropathy: a meta-analysis of studies reported between 1994 and 2004 and comprising 14,727 subjects. Diabetologia, Vol. 48, No. 5, (May), pp. 1008-1016, ISSN 0012-186X.

$\mathrm{Ng}$, DPK., Tai, BC. \& Lim, X-L. (2008) Is the presence of retinopathy of practical value in defining cases of diabetic nephropathy in genetic association studies? The experience with the ACE I/D polymorphism in 53 studies comprising 17,791 subjects. Diabetes, Vol. 57, No. 9, (September), pp. 2541-2546, ISSN 0012-1797.

$\mathrm{Ng}$, DPK. (2010) Human genetics of diabetic retinopathy: current perspectives. Journal of Ophthalmology, Vol. 2010, Article ID 172593, pp. 1-6, ISSN 2090-004X.

Nosikov, VV. (2004) Genomics of type 1 diabetes mellitus and its late complications. Molecular Biology (Mosk), Vol. 38, No. 1, (January - February), pp. 150-164, ISSN 0026-8933. 
Patterson, CC., Dahlquist, G., Harjutsalo, V., Joner, G., Feltbower, RG., Svensson, J., Schober, E., Gyürüs, E., Castell, C., Urbonaité, B., Rosenbauer, J., Iotova, V., Thorsson, AV. \& Soltész, G. (2007) Early mortality in EURODIAB population-based cohorts of type 1 diabetes diagnosed in childhood since 1989. Diabetologia, Vol. 50, No. 12, (December), pp. 2439-2442, ISSN 0012-186X.

Patterson, CC., Dahlquist, GG., Gyürüs, E., Green, A., Soltész, G. \& EURODIAB Study Group. (2009) Incidence trends for childhood type 1 diabetes in Europe during 1989-2003 and predicted new cases 2005-20: A multicentre prospective registration study. The Lancet, Vol. 373, No. 9680, (13 June), pp 2027-2033, ISSN 0140-6736.

Pezzolesi, MG., Poznik, GD., Mychaleckyj, JC., Paterson, AD., Barati, MT., Klein, JB., Ng, DP., Placha, G., Canani, LH., Bochenski, J., Waggott, D., Merchant, ML., Krolewski, B., Mirea, L., Wanic, K., Katavetin, P., Kure, M., Wolkow, P., Dunn, JS., Smiles, A., Walker, WH., Boright, AP., Bull, SB., DCCT/EDIC Research Group, Doria, A., Rogus, JJ., Rich, SS., Warram, JH. \& Krolewski, AS. (2009) Genome-wide association scan for diabetic nephropathy susceptibility genes in type 1 diabetes. Diabetes, Vol. 58, No. 6, (June), pp. 1403-1410, ISSN 0012-1797.

Potenza, MA, Gagliardi, S., Nacci, C., Carratu, MR. \& Montagnani, M. (2009) Endothelial dysfunction in diabetes: from mechanisms to therapeutic targets. Current Medicinal Chemistry, Vol. 16, No. 6, pp. 94-112, ISSN 0929-8673.

Qidwai, T. \& Jamal, F. (2010) Inducible nitric oxide synthase (iNOS) gene polymorphism and disease prevalence. Scandinavian Journal of Immunology, Vol. 72, No. 5, (November), pp. 375-387, ISSN 1365-3083.

Ringel, J., Beige, J., Kunz, R., Distler, A. \& Sharma, AM. (1997) Genetic variants of the reninangiotensin system, diabetic nephropathy and hypertension. Diabetologia, Vol. 40, No. 2, (January), pp. 193-199, ISSN 0012-186X.

Ruggenenti, P., Bettinaglio, P., Pinares, F. \& Remuzzi, G. (2008) Angiotensin converting enzyme insertion/deletion polymorphism and renoprotection in diabetic and nondiabetic nephropathies. Clinical Journal American Society of Nephrology, Vol. 3, No. 5, (September), pp. 1511-1525, ISSN 1555-9041.

Schrijvers, BF., De Vriese, AS. \& Flyvbjerg, A. (2004) From hyperglycemia to diabetic kidney disease: the role of metabolic, hemodynamic, intracellular factors and growth factors/cytokines. Endocrine Reviews, Vol. 25, No. 6, (December), pp. 971-1010, ISSN 0163-769X.

Shaw, JE., Sicree, RA. \& Zimmet, PZ. (2010) Global estimates of the prevalence of diabetes for 2010 and 2030. Diabetes Research and Clinical Practice, Vol. 87, No. 1, (January), pp. 4-14, ISSN 0168-8227.

Spinarová, L., Spinar, J., Vasku, A., Pávková-Goldbergová, M., Ludka, O., Tomandl, J. \& Vítovec, J. (2008) Genetics of humoral and cytokine activation in heart failure and its importance for risk stratification of patients. Experimental and Molecular Pathology, Vol. 84, No. 3, (June), pp. 251-255, ISSN 0014-4800.

Stehouwer, CDA. (2000) Dysfunction of the vascular endothelium and the development of renal and vascular complications in diabetes. In: The Kidney and Hypertension in Diabetes Mellitus, E. Mogensen (Ed), 179-192, Kluwer Academic Publishers, ISBN 9780792379010, Boston, USA. 
Tarnow, L., Kjeld, T., Knudsen, E., Major-Pedersen, A. \& Parving, H-H. (2000) Lack of synergism between long-term poor glycaemic control and three gene polymorphisms of the renin angiotensin system on risk of developing diabetic nephropathy in Type I diabetic patients. Diabetologia, Vol. 43, No. 6, (June), pp. 794799, ISSN 0012-186X.

Taverna, MJ., Elgrably, F., Selmi, H., Selam, JL. \& Slama, G. (2005) The T-786C and C774T endothelial nitric oxide synthase gene polymorphisms independently affect the onset pattern of severe diabetic retinopathy. Nitric Oxide, Vol. 13, No. 1, (August), pp. 88-92, ISSN 1089-8603.

Todd, JA. (1991) A protective role of the environment in the development of type 1 diabetes? Diabetic Medicine, Vol. 8, No. 10, (December), pp. 906-910, ISSN 0742-3071.

Todd, JA., Walker, NM., Cooper, JD., Smyth, DJ., Downes, K., Plagnol, V., Bailey, R., Nejentsev, S., Field, SF., Payne, F., Lowe, CE., Szeszko, JS., Hafler, JP., Zeitels, L., Yang, JHM., Vella, A., Nutland, S., Stevens, HE., Schuilenburg, H., Coleman, G., Maisuria, M., Meadows, W., Smink, LJ., Healy, B., Burren, OS., Lam, AAC., Ovington, NR., Allen, J., Adlem, E., Leung, H-T., Wallace, C., Howson, JMM., Guja, C., Ionescu-Tîrgovişte, C., Genetics of Type 1 Diabetes in Finland, Simmonds, MJ., Heward, JM., Gough, SCL., Dunger , DB., the Wellcome Trust Case Control Consortium, Wicker, LS. \& Clayton, DG. (2007) Robust associations of four new chromosome regions from genome-wide analyses of type 1 diabetes. Nature Genetics, Vol. 39, No. 7, (July), pp. 857-864, ISSN 10614036.

Van Ittersum, FJ., de Man, AME., Thijssen, S., de Knijff, P., Slagboom, E., Smulders, Y., Tarnow, L., Donker AJM., Bilo, HJG. \& Stehouwer, CDA. (2000) Genetic polymorphisms of the renine-angiotensin system and complications of insulindependent diabetes mellitus. Nephrology Dialysis Transplantation, Vol.15, No. 7, (July), pp.1000-1007, ISSN 0931-0509.

Zanchi, A., Moczulski, DK., Hanna, LS., Wantman, M., Warram, JH. \& Krolewski, AS. (2000) Risk of advanced diabetic nephropathy in type 1 diabetes is associated with endothelial nitric oxide synthase gene polymorphism. Kidney International, Vol. 57, No. 2, (February), pp. 405-413, ISSN 0085-2538.

Zhou, JB. \& Yang, JK. (2010) Angiotensin-converting enzyme gene polymorphism is associated with proliferative diabetic retinopathy: a meta-analysis. Acta Diabetologica, Vol. 47, Suppl. 1, (December), pp. 187-193, ISSN 0940-5429.

Zintzaras, E., Papathanasiou, AA. \& Stefanidis, I. (2009) Endothelial nitric oxide synthase gene polymorphisms and diabetic nephropathy: a HuGE review and meta-analysis. Genetics in Medicine, Vol. 11, No. 10, (October), pp. 695-706, ISSN 1098-3600.

Zotova, EV., Voron'ko, OE., Bursa, TR., Galeev, IV., Strokov, IA. \& Nosikov, VV. (2005) Polymorphic markers of the NO synthase genes and genetic predisposition to diabetic polyneuropathy in patients with type 1 diabetes mellitus. Molecular Biology (Mosk), Vol. 39, No. 2, (March - April), pp. 224-229, ISSN 0026-8933.

Yilmaz, G., Esser, P., Kociok, N., Aydin, P. \& Heimann, K. (2000) Elevated vitreous nitric oxide levels in patients with proliferative diabetic retinopathy. American Journal of Ophthalmology, Vol. 130, No. 1, (July), pp. 87-90, ISSN 0002-9394. 
Wang, Y., Newton, DC. \& Marsden, PA. (1999) Neuronal NOS: gene structure, mRNA diversity, and functional relevance. Critique Review Neurobiology, Vol. 13, No. 1, pp. 21-43, ISSN 0892-0915.

Warpeha, KM., Xu, W., Liu, L., Charles, IG., Patterson, CC., Ah-Fat, F., Harding, S., Hart, PM., Chakravarthy, U. \& Hughes, AE. (1999) Genotyping and functional analysis of a polymorphic (CCTTT)(n) repeat of NOS2A in diabetic retinopathy. FASEB Journal, Vol. 13, No. 13, (October), pp. 1825-1832, ISSN 0892-6638.

Warpeha, KM. \& Chakravarthy, U. (2003) Molecular genetics of microvascular disease in diabetic retinopathy. Eye (London), Vol. 17, No. 3, (April), pp. 305-311, ISSN 0950$222 X$. 


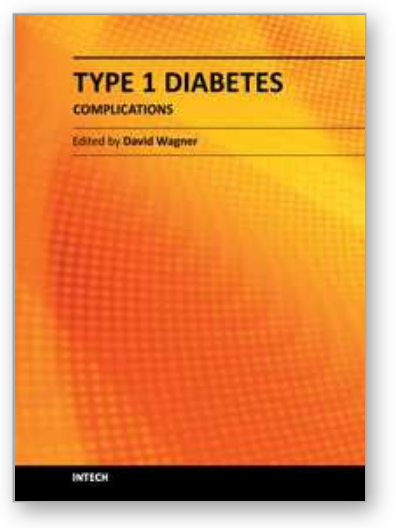

\author{
Type 1 Diabetes Complications \\ Edited by Prof. David Wagner
}

ISBN 978-953-307-788-8

Hard cover, 482 pages

Publisher InTech

Published online 25, November, 2011

Published in print edition November, 2011

This book is a compilation of reviews about the complication of Type 1 Diabetes. T1D is a classic autoimmune disease. Genetic factors are clearly determinant but cannot explain the rapid, even overwhelming expanse of this disease. Understanding etiology and pathogenesis of this disease is essential. The complications associated with T1D cover a range of clinical obstacles. A number of experts in the field have covered a range of topics for consideration that are applicable to researcher and clinician alike. This book provides apt descriptions of cutting edge technologies and applications in the ever going search for treatments and cure for diabetes.

\title{
How to reference
}

In order to correctly reference this scholarly work, feel free to copy and paste the following:

Constantina Heltianu, Cristian Guja and Simona-Adriana Manea (2011). Genetic Determinants of Microvascular Complications in Type 1 Diabetes, Type 1 Diabetes Complications, Prof. David Wagner (Ed.), ISBN: 978-953-307-788-8, InTech, Available from: http://www.intechopen.com/books/type-1-diabetescomplications/genetic-determinants-of-microvascular-complications-in-type-1-diabetes

\section{INTECH}

open science | open minds

\section{InTech Europe}

University Campus STeP Ri

Slavka Krautzeka 83/A

51000 Rijeka, Croatia

Phone: +385 (51) 770447

Fax: +385 (51) 686166

www.intechopen.com

\section{InTech China}

Unit 405, Office Block, Hotel Equatorial Shanghai

No.65, Yan An Road (West), Shanghai, 200040, China 中国上海市延安西路65号上海国际贵都大饭店办公楼 405 单元

Phone: +86-21-62489820

Fax: $+86-21-62489821$ 
(C) 2011 The Author(s). Licensee IntechOpen. This is an open access article distributed under the terms of the Creative Commons Attribution 3.0 License, which permits unrestricted use, distribution, and reproduction in any medium, provided the original work is properly cited. 